\title{
Myco-Nourishment from the Wild: Chemical Analyses of the Nutritional and Amino Acid Profile of Termitomyces robustus Harvested from Uzuakoli, Nigeria
}

\author{
Ifeoma I ljeh ${ }^{1 *}$, ljeoma N Eke ${ }^{1}$, Callistus C Ugwu ${ }^{1}$ and Chukwunonso ECC Ejike ${ }^{2 *}$ \\ ${ }^{1}$ Department of Biochemistry, College of Natural Sciences, Michael Okpara University of Agriculture, Umudike, PMB 7267 Umuahia, Abia State, Nigeria \\ ${ }^{2}$ Department of Medical Biochemistry, Faculty of Basic Medical Sciences, Federal University, Ndufu-Alike, Ikwo, PMB 1010 Abakaliki, Ebonyi State, Nigeria
}

\begin{abstract}
Though there are reports on the nutritional and phytochemical compositions of edible mushrooms in Nigeria, there is as yet no report on Termitomyces robustus sourced from the rainforest zone of South-Eastern Nigeria. To fill this knowledge-gap, fresh samples of Termitomyces robustus were purchased from locals in Uzuakoli, Abia State, Nigeria. They were sorted, cleaned up and pulverised into a fine powder. Proximate, anti-nutrient and amino acid composition of the powder were determined using standard methods. The macro-nutrients profile in general showed that Termitomyces robustus is a rich source of protein $(33.8 \pm 0.3 \%)$ with an excellent amino acid composition. It also had high carbohydrate content $(54.3 \pm 0.2 \%)$ but minimal fat content $(3.4 \pm 0.0 \%)$. The energy content of Termitomyces robustus was calculated to be $382.6 \pm 1.4 \mathrm{kcal} / \mathrm{g}$. The mushrooms are also good sources of minerals such as potassium, phosphorous, magnesium and calcium. Anti-nutritional factors such as oxalates, tannins and trypsin inhibitors were found to be present in the mushroom in small quantities. These findings indicate that Termitomyces robustus is a low energy, health-food that may provide the relevant nutrients without the burden of excess calories.
\end{abstract}

Keywords: Nutrients; Anti-nutrients; Termitomyces robustus; Mushrooms

\section{Introduction}

There is a growing need for food, especially those rich in protein, to meet the demands of Nigeria's rapidly growing population. Given the shortfalls in protein supplies from most popular sources (beef, poultry and fish), alternatives such as the edible macrofungi, mushrooms, have become desirable [1]. Most of the edible mushrooms consumed in Nigeria are sourced from the wild due to an absence of investments in mushroom farming [2]. An estimated twenty-five species of edible mushrooms are used for nutritional and medicinal purposes in Nigeria [3]. One of the most delicious species is the Paleo-tropical Termitomyces robustus [4]. Species of the genus Termitomyces are usually characterised by their association with termites, known as "fungus growers" (Macrotermitinae; which grow about 30 species of Termitomyces worldwide) [5]. Termitomyces species also have pinkish sore print, prominent perforatorium on the pileus and subterranean pseudorhiza connected to the termite's comb. They are however currently not cultivated due to the difficulty in cultivation imposed by their very specific natural growth requirement - an obligate symbiotic association with termites $[4,5]$. Edible mushrooms are typically collected between the months of August and October from the wild, early in the mornings, usually by women and children $[4,6]$.

Mushrooms have been studied for their nutritional and antinutritional constitution as well as their therapeutic potentials. There are reports showing that they are rich in nutrients [4,7-10]; and that they contain bioactives which exhibit a variety of biological properties such as antibacterial, antiviral, anti-mutagenic and anti-tumoral activities $[11,12]$. Unfortunately there are no reports on the chemical composition of Termitomyces robustus harvested from forests in the South-Eastern parts of Nigeria. Given the variations reported in the composition of the mushrooms harvested from different parts of Nigeria in particular, and the world in general, it is important to fill-in this knowledge gap, hence this study.

\section{Materials and Methods}

\section{Sample collection}

Fresh samples of Termitomyces robustus were purchased from a local market in Uzuakoli, Bende Local Government Area, Abia State, Nigeria. Abia State is in the South-Eastern part of Nigeria and the vegetation is typical of the tropical rainforest zone of Nigeria. Most months of the year are warm and humid, and therefore support the growth of mushrooms (Figure 1). The samples were identified by Prof. IC Okwulehie, a Mycologist in the Plant Science and Biotechnology Department, Michael Okpara University of Agriculture, Umudike.

\section{Sample preparation}

The fresh samples of Termitomyces robustus were sorted, cleaned and weighed to get the fresh weight. The samples were cut into smaller sizes and air dried under a shade for two weeks. After air- drying, the dry sample was weighed to get the dry weight and was thereafter pulverised into a powder, using a laboratory blender.

\section{Proximate analysis of Termitomyces robustus}

The moisture content of the mushrooms was determined gravimetrically. The fat content was determined using a Soxhlet

${ }^{*}$ Corresponding authors: Ifeoma I ljeh, Department of Biochemistry, College of Natural Sciences, Michael Okpara University of Agriculture, Umudike, PMB 7267 Umuahia, Abia State, Nigeria, Tel: +2348064719842; E-mail: ijehirene@yahoo.com

Chukwunonso ECC Ejike, Department of Medical Biochemistry, Faculty of Basic Medical Sciences, Federal University, Ndufu-Alike, Ikwo, PMB 1010 Abakaliki, Ebonyi State, Nigeria, E-mail: nosoejikeecc@yahoo.com

Received May 04, 2016; Accepted May 20, 2016; Published May 26, 2016

Citation: ljeh II, Eke IN, Ugwu CC, Ejike ECCC (2016) Myco-Nourishment from the Wild: Chemical Analyses of the Nutritional and Amino Acid Profile of Termitomyces robustus Harvested from Uzuakoli, Nigeria. Nat Prod Chem Res 4 225. doi:10.4172/2329-6836.1000225

Copyright: @ 2016 ljeh II, et al. This is an open-access article distributed under the terms of the Creative Commons Attribution License, which permits unrestricted use, distribution, and reproduction in any medium, provided the original author and source are credited. 




Figure 1: Site of sample collection.

apparatus by extracting a known weight of sample with petroleum ether as described by Pearson [13] while the total carbohydrates were determined by the method of Jurgen and Moller [14]. Total fibre, ash (determined by incineration at $600 \pm 15^{\circ} \mathrm{C}$ ) and crude protein (by the macro-Kjeldahl method; $\mathrm{N} \times 4.38$ ) contents were determined as described by AOAC [15]. Total energy was calculated according to the following equation:

Energy $(\mathrm{kcal})=4 \times[$ protein $(\mathrm{g})+$ carbohydrates $(\mathrm{g})]+9 \times$ fat $(\mathrm{g})$

Elemental analysis was performed by atomic absorption spectrophotometry subsequent to wet ashing as described by Harbourne et al. [16]. Anti-nutrient factors in the mushrooms were also determined using the method described by Harbourne et al. [16]. Amino acid analysis was carried out using an amino acid analyser, following the method described by Sparkman et al. [17]. The mushroom powder was defatted by Soxhlet extraction with chloroform methanol mixture $(2: 1)$. The defatted sample was acid-hydrolysed with $\mathrm{HCl}$ at $110^{\circ} \mathrm{C}$ for 22 hours. The hydrolysed sample was dried in a desiccator containing $\mathrm{NaOH}$ pellets under vacuum and the residue was thereafter dissolved in acetate buffer ( $\mathrm{pH}$ 2.0). The solution was then centrifuged and the supernatant filtered through a Millipore membrane $(0.22 \mu \mathrm{m}$ pore size) and loaded into the amino acid analyser. Norleucine (treated with $\mathrm{HCl}$ ) was used as an internal standard.

\section{Results and Discussion}

A moisture content of approximately $86 \%$ was found for Termitomyces robustus in thus study. Similar high moisture contents have been reported by previous authors for fresh mushrooms [18]. Carbohydrates constituted $54 \%$ of the dry Termitomyses robustus matter while proteins constituted 34\% (Table 1). The findings are similar to those of Ogundana and Fagade [4] who reported that the protein content of T. robustus was $36.4 \%$ and Aletor [8] who found that the mushroom had 33.8\% protein. Oboh and Shodehinde [9] reported slightly lower protein content for T. robustus (28.6\%). Significantly lower protein contents of the mushroom were reported by Fasidi and Kadiri [7] (16.6\%) and Obodai et al. [10] (14.8\%). The protein content was relatively high and also compared favourably with the values reported for most legumes except groundnut and soybeans grown in 
West Africa. This high protein content is not surprising however as Termitomyces sp. have been reported to be richer in protein content than other edible mushrooms in Nigeria [9].

The carbohydrate content reported here is clearly lower than that reported by Obodai et al. [10] (77.6\%), but higher than the $32.3 \%$ independently reported by Ogundana and Fagade [4] and Oboh and Shodehinde [9]. It is also considerably higher than values reported for other Termitomyces species such as T. microcarpus $(46.53 \pm 1.01)$ and T. heimi $(39.03 \pm 0.96)[19,20]$. The $3.4 \%$ fat content reported in this study is higher than $1.4 \%$ reported by Obodai et al. [10], but lower than values reported by previous authors who found that fats constituted $4.6 \%$ [7], $7.8 \%$ [4], and $12.5 \%$ [9] of the mushroom. The energy value calculated from the above discussed indices was similar to that reported by Obodai et al. [10] ( $382.6 \pm 1.4$ vs $382.3 \pm 1.3$, respectively). The crude fibre content of T. robustus found in this study $(6.3 \%)$ is close to the values $(5-9 \%)$ reported by previous authors $[4,7,9]$ with the exception of Aletor [8] who reported a crude fibre content of $3.7 \%$. The reported crude fibre content is especially important due to the interesting role fibre has been found to play in the maintenance of proper bowel movement and the prevention of colon cancer.

The data from Table 2 shows that T. robustus is rich in potassium, phosphorous, magnesium, calcium, sodium and iron. Zinc, copper and manganese were also found in modest quantities while selenium was found to be present in small quantities in the mushroom. Though many of these mineral elements have been reported in varying degrees by some previous authors $[7,8,10]$, this is the first report (to the authors' knowledge) of the presence of the anti-oxidant element, selenium, in $T$. robustus. The minerals, mainly potassium, phosphorus, iron and sodium in T. robustus was higher than those reported for T. mammiformis and several cowpea varieties but slightly lower than those recorded for fish, snail and broiler meat $[19,21,22]$. These mineral elements are nonetheless necessary when consumed in adequate quantities as some of them are cofactors and are essential in most enzymatic activities while others are useful in the maintenance of osmotic balance.

The results of anti-nutritional factors are shown in Table 3. Tannins, oxalates, cyanogenic glycosides and trypsin inhibitors were found in low quantities in Termitomyces robustus. The presence of these anti-nutritional factors was reported earlier by Aletor [8]. These antinutrients bind to nutrients and render them unavailable biologically. For example, phytic acid chelates mineral elements especially calcium, magnesium, iron and zinc and therefore can result in deficiencies of these minerals. Though the values reported here are low, and in fact lower than values reported for legumes [8], and there are no claims to the authors' knowledge of poisoning arising from the consumption of T. robustus, proper processing of the mushrooms before consumption is still important. Interestingly very basic processing techniques such as boiling are known to drastically reduce the anti-nutrient composition of foods.

The results of the amino acid analysis (Table 4) indicate that the protein of Termitomyces robustus contains all the exogenous amino acids even though some are present in low concentrations. The concentrations of the different amino acids were clearly higher than values reported for the mushroom by Alofe [23]. The said author also noted that the amino acids found in the mushroom are better than those reported for popularly consumed Nigerian vegetables. The copious presence of many amino acids may lend credence to the popular use of $T$. robustus traditionally as protein source in foods. Even though the protein content is lower than that found in eggs, meat and fish, it is adequate to be used as a substitute in the diet of the general public, especially where more traditional protein sources are scarce.

\begin{tabular}{|c|c|}
\hline Nutrient & Constitution $\mathbf{( g / 1 0 0 ~ g ~ d r y ~ m a t t e r ) ~}$ \\
\hline Carbohydrate & $54.3 \pm 0.2$ \\
\hline Protein & $33.7 \pm 0.3$ \\
\hline Ash & $8.5 \pm 0.1$ \\
\hline Crude fiber & $6.3 \pm 0.1$ \\
\hline Fat & $3.4 \pm 0.0$ \\
\hline Energy value (kcal) & $382.6 \pm 1.4$ \\
\hline
\end{tabular}

Table 1: Nutrient composition and energy value of Termitomyces robustus.

\begin{tabular}{|c|c|}
\hline Elements & Concentration $\mathbf{( m g / 1 0 0 ~} \mathbf{g})$ \\
\hline Potassium & $2451.8 \pm 41.3$ \\
\hline Phosphorus & $604.0 \pm 8.7$ \\
\hline Magnesium & $91.3 \pm 1.2$ \\
\hline Calcium & $57.0 \pm 1.7$ \\
\hline Sodium & $35.4 \pm 1.6$ \\
\hline Iron & $17.9 \pm 1.0$ \\
\hline Zinc & $8.5 \pm 0.4$ \\
\hline Copper & $3.4 \pm 0.2$ \\
\hline Manganese & $2.1 \pm 0.0$ \\
\hline Selenium & $0.1 \pm 0.0$ \\
\hline
\end{tabular}

Table 2: Mineral composition of Termitomyces robustus.

\begin{tabular}{|c|c|}
\hline Anti-nutrient & Constitution (\%) \\
\hline Cyanogenic glycosides & $9.0 \pm 0.1$ \\
\hline Trypsin inhibitor & $8.0 \pm 1.0$ \\
\hline Oxalate & $0.3 \pm 0.0$ \\
\hline Tannins & $0.2 \pm 0.0$ \\
\hline
\end{tabular}

Table 3: Anti-nutritional components of Termitomyces robustus.

\begin{tabular}{|c|c|c|}
\hline Amino acid & $\begin{array}{c}\text { Concentration (g/100 g } \\
\text { protein) }\end{array}$ & WHO Ref. ( g/100 g protein) \\
\hline Leucine & $7.1 \pm 0.3$ & 5.5 \\
\hline Valine & $5.2 \pm 0.1$ & 3.2 \\
\hline Lysine & $5.0 \pm 0.1$ & 5.1 \\
\hline Threonine & $4.8 \pm 0.2$ & 2.7 \\
\hline Isoleucine & $4.8 \pm 0.1$ & 2.5 \\
\hline Histidine & $2.2 \pm 0.0$ & 1.8 \\
\hline Meth+Cyst & $2.9 \pm 0.2$ & 2.5 \\
\hline Tryptophan & $1.4 \pm 0.1$ & 0.7 \\
\hline Pheny+Cyst & $13.0 \pm 0.1$ & 4.7 \\
\hline
\end{tabular}

Table 4: Essential amino acid composition of Termitomyces robustus.

In conclusion, Termitomyces robustus harvested from forests in Uzuakoli, Abia State Nigeria were found to be rich in proteins (with an excellent amino acid composition), carbohydrates and minerals (especially potassium, phosphorous, magnesium and calcium). Low concentrations of anti-nutritional factors were also found in the mushroom. There are clear differences in the nutrient and anti-nutrient composition of T. robustus harvested from different geographic areas, even within Nigeria. Methodological differences however warrant a cautious interpretation of these differences and necessarily foreclose any comment about which source is better than the other(s).

\section{References}

1. Ayodele SM, Okhuoya JA (2009) Nutritional and phytochemical evaluation of cultivated Psathyrella atroumbonata Pegler, a Nigerian edible mushroom. S Afr J Sci 105: 158-160.

2. Okhuoya JA, Akpaja EO, Osemwegie OO, Oghenekaro AO, Ihayere CA (2010) Nigerian mushrooms: Underutilized non-wood forest resources. J Appl Sci Environ Manage 14: 43-54

3. Labarère J, Menini GU (1998) Collection, characterization, conservation and utilization of mushrooms, germplasm resources in Africa. In: The Proceedings 
Citation: Ijeh II, Eke IN, Ugwu CC, Ejike ECCC (2016) Myco-Nourishment from the Wild: Chemical Analyses of the Nutritional and Amino Acid Profile of Termitomyces robustus Harvested from Uzuakoli, Nigeria. Nat Prod Chem Res 4: 225. doi:10.4172/2329-6836.1000225

of the First International Congress for the Characterization, Conservation, Evaluation and Utilization of Mushroom Genetic Resources for Food and Agriculture. FAO, Bordeaux, France, pp: 9-13.

4. Ogundana SK, Fagade OE (1982) Nutritive value of some Nigerian edible mushrooms. Food Chem 8: 263-268.

5. Kirk P, Cannon PF, Minter DW, Stalpers JA (2008) Ainsworth and Bisby's Dictionary of the Fungi. 10th edn. CAB International: Wallingford, UK.

6. Okhuoya JA (1997) Mushroom cultivation: the Nigerian experience. Food processing technologies for Africa-emerging technologies series. UNIDO, pp: 153-168.

7. Fasidi IO, Kadiri M (1990) Changes in nutrient contents of two Nigerian mushrooms, Termitomyces robustus (Beeli) Heim and Lentinus subnudus Berk, during sporophore development. Die Nahrung 34: 415-420.

8. Aletor VE (1995) Compositional studies on edible tropical species of mushrooms. Food Chem 54: 265-268.

9. Oboh G, Shodehinde SA (2009) Distribution of nutrients, polyphenols and antioxidant activities in the pilei and stipes of some commonly consumed edible mushrooms in Nigeria. Bull Chem Soc Ethiop 23: 391-398.

10. Obodai M, Ferreira IC, Fernandes A, Barros L, Mensah DL, et al. (2014) Evaluation of the chemical and antioxidant properties of wild and cultivated mushrooms of Ghana. Molecules 19: 19532-19548.

11. García-Lafuente A, Moro C, Villares A, Guillamón E, Rostagno MA, et al. (2010) Mushrooms as a source of anti-inflammatory agents. Am J Comm Psychol 48 125-141.

12. Schillaci D, Arizza V, Gargano ML, Venturella G (2013) Antibacterial activity of Mediterranean Oyster mushrooms, species of genus Pleurotus (higher Basidiomycetes). Int J Med Mushrooms 15: 591-594.
13. Pearson DA (1976) Chemical analysis of foods. 7th edn. Churchill Livingstone, Edinburgh.

14. Hansen J, Moller I (1975) Percolation of starch and soluble carbohydrates from plant tissue for quantitative determination with anthrone. Anal Biochem 68: 87-94.

15. AOAC (1980) Official methods of Analysis. Association of Official Analytical Chemists. Washington DC, USA.

16. Harbourne JB (1973) Phytochemical Methods: A Guide to Modern Techniques of Plants Analysis. Chapman and Hill Ltd, London, pp: 183-187.

17. Sparkman DH, Stein EH, Moore S (1958) Automatic recording apparatus for use in chromatography of amino acids. Analyt Chem 30: 1190-1206.

18. Gbolagade J, Ajayi A, Oku I, Wankasi D (2006) Nutritive value of common wild edible mushrooms from Southern Nigeria. Global J Biotech Biochem 1: 16-21.

19. Adejumo TO, Awosanya OB (2005) Proximate and mineral composition of four edible mushroom species from south western Nigeria. Afric J Biotech 4: 1084 1088

20. Johnsy G, Davidson S, Dinesh MG, Kaviyarasan V (2011) Nutritive value of edible mushroom collected from Western ghats of Kanyakumari district. Bot Res Int 4: 69-74.

21. Aletor VA, Aladetimi OO (1989) Compositional evaluation of some cowpea varieties and some under-utilized edible legumes in Nigeria. Nahrung 33: 999-1007.

22. Imevbore EA (1992) Perspectives of snail farming in tropical Africa. The Nigerian Situation. In proc. Invertebrates (Microlivestocks) Farming Seminar, La union Philipines.

23. Alofe FV (1991) Amino acids and trace minerals of three edible wild mushrooms from Nigeria. J Food Comp Anal 4: 167-174 